\title{
Urban Flooding Mitigation Techniques: A Systematic Review and Future Studies
}

\author{
Yinghong Qin 1,2 \\ 1 College of Civil Engineering and Architecture, Guilin University of Technology, Guilin 541004, China; \\ yqin1@mtu.edu; Tel.: +86-0771-323-2464 \\ 2 College of Civil Engineering and Architecture, Guangxi University, 100 University Road, \\ Nanning 530004, China
}

Received: 20 November 2020; Accepted: 14 December 2020; Published: 20 December 2020

\begin{abstract}
Urbanization has replaced natural permeable surfaces with roofs, roads, and other sealed surfaces, which convert rainfall into runoff that finally is carried away by the local sewage system. High intensity rainfall can cause flooding when the city sewer system fails to carry the amounts of runoff offsite. Although projects, such as low-impact development and water-sensitive urban design, have been proposed to retain, detain, infiltrate, harvest, evaporate, transpire, or re-use rainwater on-site, urban flooding is still a serious, unresolved problem. This review sequentially discusses runoff reduction facilities installed above the ground, at the ground surface, and underground. Mainstream techniques include green roofs, non-vegetated roofs, permeable pavements, water-retaining pavements, infiltration trenches, trees, rainwater harvest, rain garden, vegetated filter strip, swale, and soakaways. While these techniques function differently, they share a common characteristic; that is, they can effectively reduce runoff for small rainfalls but lead to overflow in the case of heavy rainfalls. In addition, most of these techniques require sizable land areas for construction. The end of this review highlights the necessity of developing novel, discharge-controllable facilities that can attenuate the peak flow of urban runoff by extending the duration of the runoff discharge.
\end{abstract}

Keywords: urban stormwater management; green roofs; permeable pavements; low-impact development; bio-retention

\section{Introduction}

Most of rainwater reaching the ground surface either infiltrates the soil or returns to the air by evaporation and evapotranspiration. Urbanization has sealed natural soils by pavements, roofs, and other impervious surfaces, constraining natural infiltration and evapotranspiration and converting rainfall into runoff [1,2]. Runoff from open soils in urbanized areas is also increasing because construction activities have compacted soils to behave like impermeable surfaces [3,4]. Traditionally, engineered facilities such as gutters, channels, and pipes are built to convey runoff from sealed surfaces to centralized detention ponds, retention facilities, and nearby streams as quickly as possible. In heavy rainfall, these facilities usually fail to compete with the superimposed peak flows discharging from different sealed surfaces, leading to overflow and flooding [5].

Across the globe, on-site treatment techniques have been recently applied, either separately or in combination, to retain, detain, infiltrate, harvest, evaporate, transpire, or re-use rainwater on the source and thus to reduce both the urban runoff volume and runoff peak discharge. On-site stormwater treatment approaches are termed as Integrated Urban Water Management [6], Water Sensitive Urban Design [7], low impact development [8], Active Beautiful Clean [9], Sponge Cities [10], Sustainable Urban Drainage system [11], and other similar terminologies. While the terms are different, their 
planning and designing principles are similar, with the same goal of restoring pre-development hydrology by treating rainwater at the source $[12,13]$. While some of these approaches may not be purposed primarily to mitigate urban flooding, they have co-benefits of mitigating urban flooding by reducing the runoff volume and attenuating the peak-flow discharge.

Pratt [14] had reviewed rainwater source-control techniques categorizing them into ground-surface and below-ground approaches. Dietz [15] reviewed the practices of low impact development, with a focus on water quality improvement rather than on urban flooding mitigation. Recently, Ahiablame et al. [16] reviewed the benefits related to the practice of low impact development, with a focus on water quality observation and modeling. Which the techniques to mitigate urban flooding are well documented, it is necessary to comprehensively compare the effectiveness of these techniques. This review compares mainstream techniques available to mitigate urban flooding and compiles the wide-range but diffuse literature on the topic of rainwater-runoff reduction and peak-flow attenuation. With this review, engineers, designers, and administrators can overview the mainstream flooding-control techniques. The end of the review highlights the necessity of developing novel, discharge-controllable facilities that can attenuate the peak flow of urban runoff by extending the duration of the runoff discharge.

\section{Methodology}

The review process includes two steps. First, we searched for articles in Google Scholar (https: //scholar.google.com/) using the search strings "urban flooding", "urban rainwater management", "runoff reduction", and "peak flow discharge". Only journals articles, proceedings, and reports were selected. For those papers published before 2018, only the papers that had been cited more than twice were considered. For those published after 2018, only the papers indexed by Web of Science and/or Engineering Village were candidates. After reading the abstract of each selected paper, the full-text of the paper was downloaded if the abstract is rightly related to the mitigation of urban flooding. The reference section of the downloaded papers was then scanned for any possible related papers on the topic of urban flooding. This process of reading abstract and scanning reference was repeated until no more journals articles, proceedings, and reports related to the topic of urban flooding mitigation were found. Totally, 550 papers were downloaded for deeper reading.

Second, each selected paper was read carefully. It is found that most papers reported on techniques to simultaneously reduce the runoff volume and to improve water quality. Only those papers with the core ideas on urban flooding mitigation, runoff volume reduction, and/or peak flow attenuation were selected. In this process, we found that 353 of the downloaded papers fell marginally on the topic of urban flooding mitigation, and that about 14 papers were replicated. Finally, 183 papers were included. Core findings of these papers were then integrated, synthesized, and compiled. We found that mainstream techniques for urban-flooding mitigation included green roofs, non-vegetated roof, trees, permeable pavements, water-retaining pavements, infiltration trenches, rain barrels, rainwater tanks, bioretentions, soakaways, and underground tanks. While different techniques could be grouped differently, the best way to review these techniques was to categorize them into above-ground techniques, ground-level techniques, and underground techniques (Table 1). As a review of the mainstream techniques for urban flooding mitigation, we did not intend to compare experimental and modeling data in different articles. Instead, the peak-flow attenuation capacity of each technique was schematically analyzed to illustrate the working mechanism of each technique.

Table 1. Runoff can be controlled above, on and below the ground.

\begin{tabular}{ll}
\hline Runoff-Control Sites & Facilities \\
\hline Above the ground & $\begin{array}{l}\text { green roofs, non-vegetated roof } \\
\text { trees, pervious pavements, water-retaining pavements, infiltration trenches, } \\
\text { On the ground }\end{array}$ \\
rain barrels, rainwater tanks, bioretentions \\
Below the ground & soakaways, and underground cisterns \\
\hline
\end{tabular}




\section{Above-Ground Techniques}

\subsection{Green Roofs}

Green roofs, known as vegetated roofs, eco-roofs, and natural roofs, are built by adding a plant layer and a growing medium upon to the roof deck of a traditional roof. A typical green roof has six layers including plants, a growing medium, a filter, a drainage layer, a root barrier, and a waterproof membrane (Figure 1). According to the thickness of the roof layers, a green roof with a substrate depth of $10 \mathrm{~cm}$ or less is called as an extensive roof. Intensive green roofs have a thicker substrate and a taller plant but are less commonly used than extensive green roofs.

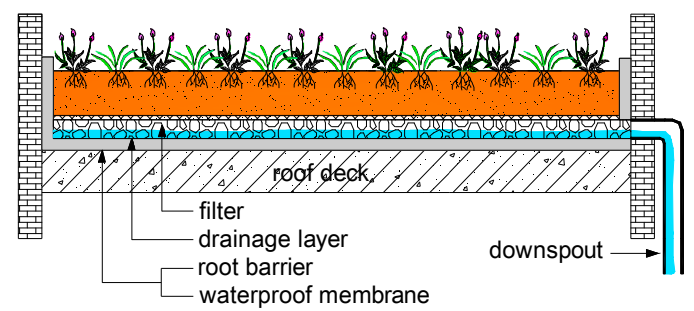

Figure 1. Rainwater falling on a green roof is retained and detained by plants and soils; additional rainfall leads to overflow.

Green roofs offer a serial of environmental benefits such as providing thermal insulation for the buildings [17], creating a habitat for wildlife [18], increasing the aesthetic appeal of the landscape [19], mitigating urban heat islands [20], sequestrating carbon dioxide [21], and others [22]. In addition, a green roof can be used as a source-control facility to reduce urban runoff [23]. Rainwater that falls on a green roof can be detained and retained in the layers of green roofs, except that additional rainwater enters downspouts and finally discharges to local sewer pipes [24]. The green roof subsequently evacuates the absorbed water via soil evaporation and plant transpiration, resetting for absorbing rainwater during the next rainfall [25].

\subsubsection{Extensive Green Roof}

The rate of rainwater retained and detained by a green roof is widely different, for instance, $13.8-60.8 \%$ [26], 12-25\% [27], 35.5-100\% [28], 32-50.4\% [29], and 19-98\% [30]. Gregoire and Clausen [31] summarized the rainwater retention of different roofs and found an average retention of $56 \%$. The runoff reduction capacity depends on the plant species, substrate depth, roof slope, antecedent dry period, rainfall depth, as well as the local climate [32]. Different plant species have different water-retaining capacities in an order of grass $>$ sedum $>$ forb [33]. Similar results are reported by [34,35]. Under the plants, a thicker roof substrate retains and detains more water and thus delays the peak flow further [36]. The annual runoff coefficient of a specific roof decreases as the thickness of substrate layer increases [37]. The water retaining capacity of a green roof is also influenced by the roof's configuration [38]. A green roof with a smaller slope retains more water in the substrate layer and thus leads to the less runoff volume [39]. The water retaining capacity of the substrate also depends on the dry period before the rain, with a longer antecedent dry period resulting in more rainwater retention in the substrate [40]. The ratio of the water retention volume to the rainfall volume decreases as the rainfall depth increases [41]. Similarly, by monitoring the water-retaining capacity of prototyped roofs, Bliss et al. [42] found that the roofs reduced the greatest amount of runoff in case of the light storm with a short duration. As rainfall depth and duration varies seasonally, the water-retaining capacity of a green roof also varies seasonally, with a greater value in summer than that in winter [43].

As the grown media retains water in the pores, the peak flow is reduced accordingly. Fassman et al. [44] measured from the water retention of four extensive green roofs and found that the peak flow is $60-90 \%$ lower than the control roof. By studying the runoff volume of a green roof and a conventional ballasted roof, Bliss et al. [42] found that the peak flow from the green roof is $5-70 \%$ 
smaller than that from the ballasted roof. The average runoff coefficient depends highly on the length of the watercourse. As a result, the peak flow can be further reduced if the flow path to the nearby gutter is lengthened and/or if flow-retarding media is used as the substrate [44]. In addition, runoff is delayed because it takes time for the media to be saturated and for rainwater to percolate through the media $[45,46]$. As the process of a soil being saturated takes hours, a green roof delays the peak flow for hours too [47]. For instance, a delay of half an hour is found in [48,49]; 2 h, in [30,50]; and 2-3 h, in [42]. The true delay of the peak flow depends mainly on the rainfall depth and rainfall intensity [39].

Identification of the peak lag times is difficult and unnecessary because the natural rainfall patterns are irregular and the water storage capacity of a green roof in a specific event varies [51]. A green roof has a high capacity to reduce rainwater especially in case of small rainfall [52]. In case of heavy rainfall, overflow is inevitable after the media are saturated [53]. As urban flooding takes place due to the superposition of the peak flows from different catchments during heavy rainfall, the retention percentage of a green roof at a small rainfall is not important. The importance is the retention depths during a heavy rainfall. As measured by DeNardo et al. [54], the retention and detention depths of a typical green roof are about $1-5 \mathrm{~cm}$, meaning that green roofs inevitably overflow in heavy rainfall. Therefore, green roofs have a marginal ability to mitigate urban flooding in case of frequent, intense, heavy, and extreme rainfall events [55].

There are some contradictory observations related to the water retention of green roofs. Whittinghill et al. [56] observed runoff quantity from traditional sedum- and prairie-covered green roofs over three growing seasons. They found that green roofs covered with prairie reduced a greater amount of runoff than sedum-covered green roofs. Vanuytrecht et al. [33] found that green roofs covered by grass or herb retained rainwater more than green roofs covered by moss sedum did. Similarly, Nagase and Dunnett et al. [35] found that green roofs covered by grass reduce the greatest runoff amount, followed by sedum, and finally forb. It is also found that plants that are taller-stem, larger-canopy, larger-shoots, and deeper-roots retain a greater amount of runoff [35]. Contrary, Buccola and Spolek [36] found that different retention is attributed to the substrate depth rather than plant species, with a thicker roof substrate retaining and detaining a greater amount of rainwater and delaying the peak discharge further. In addition, by quantifying stormwater control of green roofs with different substrate media, Voyde et al. [57] found that the antecedent dry period dictates the water retention of a green roof. This dictation indirectly indicates that the substrate depth dominates the water retention of green roofs because the antecedent dry period determines the moisture content in the substrate soils [58].

\subsubsection{Intensive Green Roofs}

An intensive green roof has a deeper substrate layer for the growth of taller plants. Compared to an extensive green roof, an intensive green roof requires more routine maintenance, is more expensive, and thus is less used [59]. Monitoring runoff from an aged intensive green roof in Manchester, UK during 69 rainfall events, Speak et al. [60] found an average runoff retention of an extensive roof was $67.5 \%$. Kolb [61] monitored the evaporation and runoff coefficients of an intensive roof as well as those of an extensive roof. It is found that compared to an extensive green roof, an intensive green roof evaporates more but discharges a less amount of runoff. Razzaghmanesh and Beecham [62] monitored the hydrologic performance of intensive and extensive green roofs for two years. They found that both roofs reduce the runoff similarly, but that an intensive green roof attenuates the peak flow greater and retard peak flow longer.

\subsection{Other Non-Vegetated Roofs}

Non-vegetated roofs such as ballast roofs or soil roofs reduce runoff as well [63]. Van Woert et al. [39] tested the runoff retention of a vegetated roof, a soil roof, and a gravel roof, of which the substrate depths were the same. The test lasted for 14 months in cases of heavy ( $>6 \mathrm{~mm})$, medium $(2-6 \mathrm{~mm})$, and light $(<2 \mathrm{~mm})$ rainfall. While the gravel roof retains the lowest percentage of rainwater, it still 
absorbs a sizable amount of rainwater. In addition, both the gravel-covered roof and the soil roof can delay the start of runoff for a quarter to a half of an hour, depending on the rainfall depth and rainfall intensity. A similar finding is reported by Carpenter and Kaluvakolanu [64], who monitored stormwater runoff of stone-ballasted roof over six months. The stone-ballasted captures about $50 \%$ of the rainfall volume, attenuates the peak-flow discharge, and delays the peak discharge for $1.2 \mathrm{~h}$. However, during the observations rainfall depths are small. In case of heavy rainfall, non-vegetated roofs also overflow as vegetated roofs do. While non-vegetated roofs are also optional for rainwater management, they are seldom used when compared to vegetated green roofs because vegetated roofs bring more benefits than non-vegetated roofs.

\section{Ground Surface Techniques}

\subsection{Permeable Pavements}

A permeable pavement system has a permeable surface course laid over a base layer, which is filled with open-graded gravels or stones (Figure 2) [65]. A filter fabric is usually placed at the bottom of the surface course for preventing water-carrying fine particles from sneaking into the base reservoir [66]. A perforated pipe is optional at the top of the base to bypass the excessive inflow for avoiding waterlogging. Typical permeable pavements include interlocking permeable pavers; soil-filled grid pavers; porous asphalt slab; porous concrete slab [67,68]. Design of these permeable pavements can be referred elsewhere, e.g. Mullaney and Lucke [65]. As a stormwater management option, permeable pavements offer multiple benefits of water purification [69], natural hydrology restoration [70], and runoff reduction [71], urban heat island mitigation [72], and tire-pavement noise reduction [73].

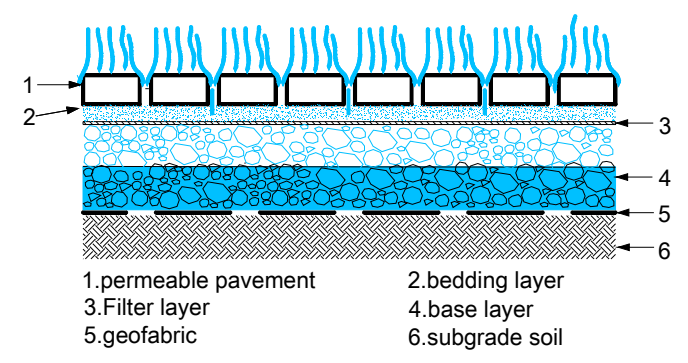

Figure 2. Rainwater falling on a permeable pavement is infiltrated to the base, which serves as a reservoir to store and infiltrate rainwater.

The hydrological performance of a permeable pavement relies on the water storage of the base and on the saturated hydraulic conductivity of the subgrade soils. The base retains rainwater temperately, which must drain timely for resetting the retention capacity before the next heavy rainfall [74]. A thicker, more-porous base layer stores a greater amount of rainwater and thus reduces possible surface runoff to a greater extent [75]. Where the soil infiltration rate is low, the stored rainwater spreads over a large soil area to infiltrate through a large area [76]. There are two ways to circumvent this problem. One is to increase the thickness of the base to restore more water during the heavy rain. Chai et al. [76] found that a permeable shoulder for a two-lane highway needs a $1.5 \mathrm{~m}$ aggregate base for the infiltration and restoration of rainwater. The other way is to line perforated pipes in the base to bypass the excessive rainwater to the nearby waterways [77,78]. Lifting up the perforated pipe increases the storage volume and the subgrade infiltration, which is helpful to restore local hydrology [79].

The type of permeable pavement significantly influences the hydrological performance [80]. Hernandez et al. [81] studied four permeable pavement systems with different surface layers and different base materials. Porous concrete overlying a recycled aggregate base retains a greater amount of runoff and delays the peak flow greater than an interlock concrete pavement over an original aggregate base. Interlock concrete blocks result in preferential flow through the gap between blocks, 
reducing the peak-flow lagtime and the water retention. Similarly, Fontaneda et al. [66] found that although a polymer-modified permeable surface course laid over a crushed-rock base reduces a greater amount of runoff than pervious pavements, the difference is negligible. Except for this small difference, various permeable pavements perform similarly in term of runoff reduction $[79,82]$. While a permeable pavement delays the infiltration and retains all rainwater in case of small rainfall, it leads to a runoff in case of heavy rain [83]. In addition, rainwater from the roof, car hoods, or other sources could saturate the nearby permeable pavements and lead to local overflow [84]. Overflow from a permeable pavement occurs when the subgrade is of low permeable soils [85].

Permeable concrete systems are prone to be clogged by fine particles [86]. Sands, scraps, organics, and other fine particles carried by runoff from other sources sneak into the cavity of the permeable pavement and lead to a clogging [87]. Implementations of permeable pavements away from soil-disturbed fields is helpful to preserve the permeability of the pavements [88]. Clogging occurred at a rapid rate at locations with high coarse sediments and organic sediment loads [89]. Particulates clogging in the near surface of a permeable pavement can be cleared by vacuum sweeping, power washing, or a combination of both [90]. These techniques, however, are not useful to clean the clog at deep locations [91]. In addition, finer particles that percolate through the permeable surface layer can finally settle at the aggregate-soil interface, reducing the infiltration of the subgrade.

\subsection{Water-Retaining Pavements}

A water-retaining pavement is either an asphalt- or cement-based paver that holds water at the top layer preferentially and evacuates the water via evaporation (Figure 3). Water-retaining pavements are also called water-holding, water-retentive, and watered pavements, or other identical terminologies [92]. These pavements are fabricated by filling water-retentive media into the pore space of pervious concrete. The fillers can be slag, mortar, moss, hydrophilic tissue, and other water-retentive media [93]. Rainwater falling on this pavement or coming from the nearby sealed surface is held at the surface course, which empties via evaporation. While water-retaining pavements are primarily designed to mitigate urban heat island effect via evaporative cooling [94], they can retain a sizeable amount of water and thus reduce runoff, especially during small rainfall. Depending on the filler materials and the depth of the filler, typically a water-retaining pavement can retain about $15 \mathrm{~kg} / \mathrm{m}^{2}$ rainwater [95]. A greater amount can be obtained by optimizing the structure of the water-retaining pavers [96]. This water-retaining capacity means that a dry water-retaining paver can fully absorb a rainfall depth of $1.5 \mathrm{~cm}$ without generating runoff [97]. A larger rainfall depth drains to the base or generates runoff when the base and subgrade have saturated. Water-retaining pavements thus also have a limited capacity to reduce the risk of urban flooding.

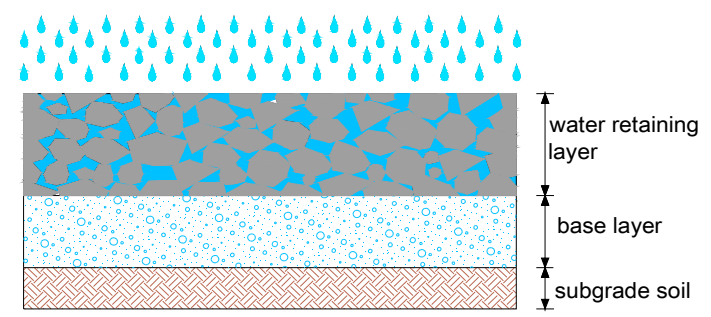

Figure 3. A water-retaining pavement holds water at the surface layer; additional water is drained to the base.

\subsection{Trees}

On urban areas, trees are widely found in parks, parking lots, gardens, streets, nature preserves, greenways, shelter-belts, and many others. Urban trees have multiple benefits such as urban heat island mitigation, air quality amendment, and others [98]. As a co-benefit, urban trees also reduce rainwater runoff by intercepting rainfall in the canopy, evaporating water from the leaves, enhancing the 
infiltration around the trees' roots, and storing water in trees' trunks (Figure 4) [99,100]. Runoff at areas with trees is reduced on different timescales. For example, the canopy intercepts rainfall immediately after rainfall starts; throughfall occurs after the canopy saturates; and evapotranspiration lasts for a long time after rainfall stops. During this process, canopy interception and ground infiltration are two main components that reduce rainwater runoff. Evaporation and transpiration of trees return water to the atmosphere, maintain the health of the trees, and restore the interception of the trees before the subsequent rainfall [101].

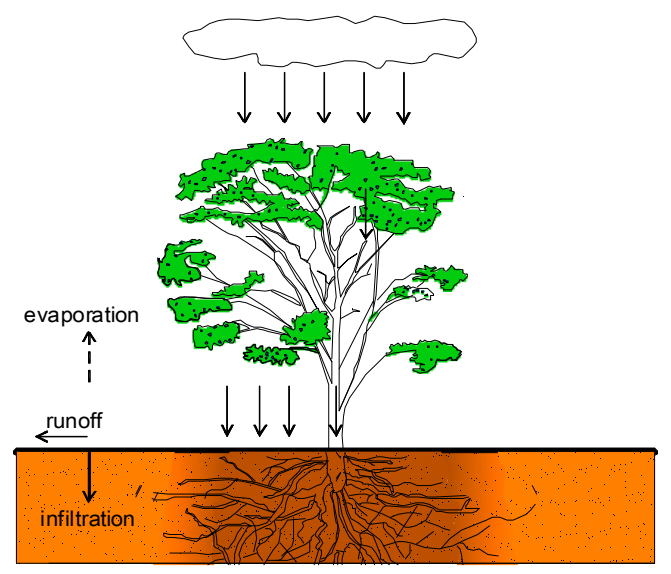

Figure 4. Rainfall falling on a tree is partitioned to interception, throughfall, infiltration, and soil retention, with the excessive water discharging as runoff.

When rain falls onto a tree, some is intercepted by the canopy, with the remainder reach the ground via throughfall or stemflow. The interception loss is the difference between the throughfall and stemflow from the gross precipitation. The interception loss of trees is found about $10-50 \%$ of seasonal or annual total rainfall [102], influenced by tree species [103] and local climate [104]. Inkiläinen et al. [105] found that the potential reduction of stormwater runoff is about 9.1-21.4\%. Xiao [106] found a rainfall interception of $15.3 \%$ for a small Jacaranda mimosifolia to $66.5 \%$ for a mature Tristania conferta. Conifers generally intercept more rainwater on the plant canopy than broadleaf trees do [107], possibly because the former has greater specific areas to intercept rainwater than the latter. For instance, Xiao et al. [104] found that the interception is about 15\% of gross precipitation for a pear tree, but $27 \%$ for an oak tree. An interception loss by a tree is also greatly influenced by climate factors such as rainfall intensity, wind speed, rainfall duration, rainfall depth, and rainfall frequency [104,108]. As different trees are applicable to different climate, planting the right trees in the right place has to be considered in urban greening [109].

A tree further reduces stormwater runoff via infiltration and detention when rainwater reaches the ground surface. Armson et al. [110] studied the infiltration into a pit with a small tree and found that the tree reduces about $60 \%$ of runoff compared to the control asphalt lot. A tree also enhances the infiltration of the underlying soils because tree roots provide conduits to convey rainwater to deep layers. The soils around a pit can be replaced by a thick porous structural soil, which serves as a reservoir to retain rainwater and to support the growth of the tree. By experimentally studying different roots growth in structural soils in the lab, Bartens et al. [111] found that the roots penetrate into compacted soils and that the infiltration of the soils increases about 150\% [112]. When designed, a tree pit should be concave to host rainwater from the nearby impervious areas for promoting rainwater natural drawdown. Although urban trees can be designed to reduce the runoff volume, they are effective in intercepting rainwater in case of small rainfall only. In case of heavy rainfall, overflow is inevitable. Urban trees are thus more meaningful to improve urban water quality than to mitigate urban flooding [113]. 


\subsection{Rainwater Barrels}

A rain barrel is a small chamber installed nearby a private building to collect rainwater from a roof downspout for later non-potable uses (Figure 5) [114]. A rain barrel is usually connected to an infiltrating lot such as a rain garden or a gravel-filled dry well. A case study by Jennings et al. [115] found that a $189 \mathrm{~L}$ rain barrel used to store rainwater from a $186 \mathrm{~m}^{2}$ roof is sufficient to irrigate $14 \mathrm{~m}^{2}$ garden in Cleveland (OH, USA), reducing 1.4-3.2\% annual runoff from the roof. Similarly, a model studied by Litofsky and Jennings [116] found that a $235 \mathrm{~L}$ rain barrel can reduce 3-44\% runoff from a traditional roof, depending on the local weather and the rainfall depth. For small rainfall, all rainwater would be retained in an empty barrel. But a rain barrel, once filled, does little to reduce excessive runoff and to store rainwater in the next rainfall [117]. In addition, homeowners are often demanded to empty the barrel routinely to restore the water retention of the barrel [115]. The use of rain barrel is thus challenged not only by barrel size but also homeowner participations [118]. For instance, Guo et al. [119] found that people who are aware of rainwater conservation are more willing to adopt rain barrels.

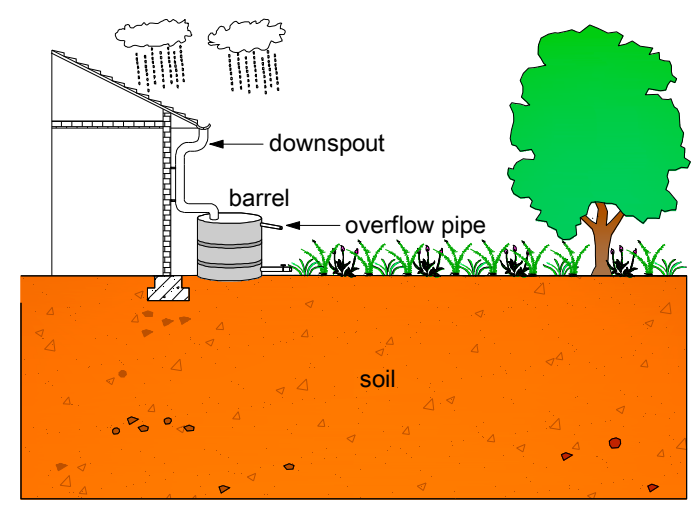

Figure 5. A rain barrel is a small chamber installed nearby a building for collecting rainwater from the downspout. The overflow can be discharged to the rain garden.

\subsection{Infiltration Trenches}

An infiltration trench, also called an infiltration ditch or a percolation trench, is a channel filled with stones or crushed rocks for storing rainwater (Figure 6) [120]. The cavities of the rocks and stones detain rainwater temporarily, which gradually infiltrates through the soil-rock interface. As the cavities of the rock are limited, infiltration trenches usually lead to overflow in case of heavy rain. Whether the water in the trench can be fully evacuated before the next heavy rainfall depends on the hydrological conductivity of the soils and on the depth of the groundwater table. An infiltration trench is feasible to the areas where the subsoils are highly permeable and where the groundwater table and the bedrock sit some meters below the bottom of the trench [121]. To maintain the permeability of the underlying soils, rainwater runoff should be pretreated by a swale (Figure 6), by a settling basin before entering the trench, or by an underdrain pipe carrying stormwater into the trench. If fine particles and settlements are not kept off the trench, especially during construction, there would be a permanent clogging. Warnaars et al. [122] monitored the runoff quantity of infiltration trenches in an urbanized area for about 3 years and found that a slight clog has decreased the infiltration of the trenches. Similar results are reported by Siriwardene et al. [123]. In addition, the use of infiltration trenches is limited by other two factors. One is that water infiltration may jeopardize the safety of the nearby buildings. The other is that most urban soils are relatively-poor infiltration. 


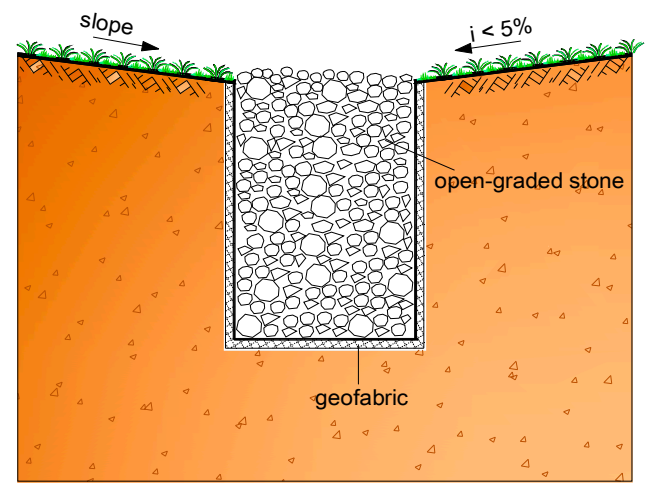

Figure 6. An infiltration trench is a channel filled with stones and gravels to detain runoff for infiltration.

\subsection{Bioretention}

\subsubsection{Rain Gardens}

Rain gardens, or bioretention areas or biofilters, are being adopted in public and private lands in urban areas to reduce stormwater volume, to attenuate peak flow, and to infiltrate rainwater that otherwise enters local sewer pipes without treatments [124-126]. Typically a rain garden is built by replacing natural soils with porous media to form a depression shallow pit for vegetated plants growth and for holding runoff from nearby sealed surfaces (Figure 7) [127,128]. A rain garden should be dry rapidly after the rain for preventing the breeding of mosquitoes. Rain gardens are often located near a building, serving as an endpoint for percolating the runoff from building roofs, patios or lawns. This process reduces local runoff, decreases the peak-flow discharge, and recharges local groundwater. Dietz and Clausen [129] built a rain garden composing of a $0.6 \mathrm{~m}$ depth well-permeable soil with a perforated pipe underlain. They found that only $0.8 \%$ of inflow left the gardens as overflow, meaning that most of the inflow (99.2\%) finally discharges as subsurface flow [129]. The hydrological performance of a real rain garden also depends on local climate [130] and the garden design [131]. While a rain garden retains a sizable amount of water and reduces the risk of overflow, the reduction was small at heavy rainfall. Therefore, a rain garden has limited capacity to reduce urban flooding [132].

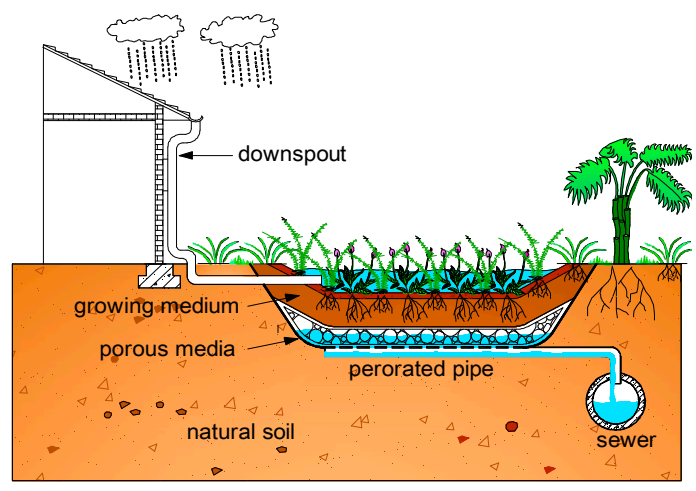

Figure 7. A rain garden is built by replacing natural soils with growth media for vegetated plants growth, which retains and filters rainwater.

\subsubsection{Vegetated Filter Strips}

A vegetative filter strip, also called biofiltration strip, filter strip and buffer strip, is a stormwater control technique that disperses rainwater uniformly as an overland sheet flow through a mildly-sloped vegetated area to promote infiltration (Figure 8) [133]. Typically the vegetated area is a filter strip with dwarf turf grass, grassy meadow or small wood for making the runoff flowing uniformly through the strip surface. Infiltration and retention of a vegetated filter strip are thus influenced by the slope, length, and plant species of the strip $[134,135]$. However, as a vegetative filter strip is primarily designed to 
intercept and slow runoff for improving the quality of the runoff, the ability of a vegetative filter strip to reduce runoff is limited. The vegetated filter strip must be pruned periodically to keep an overland sheet flow on the strip [136]. In addition, a vegetative filter strip requires lands for construction, so the most suitable place for such a strip is the side slope of a roadway embankment [136].

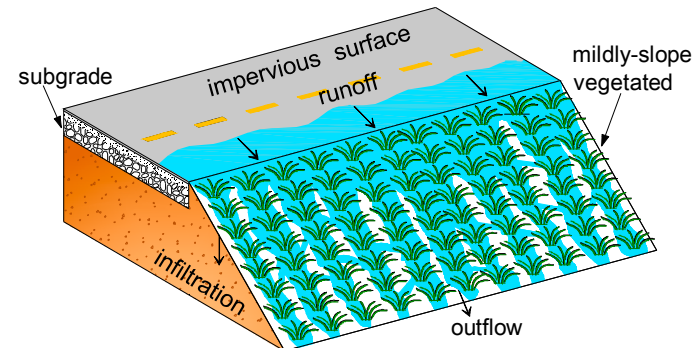

Figure 8. A vegetative filter strip is usually built nearby an impervious surface to allow runoff from the impervious surface flowing evenly through the strip for intercepting and slowing runoff.

Vegetative filter strips have been refined to level-spreader vegetative filter strips, which introduce a concrete channel with a level spreader that disperses runoff to a vegetated filter strip for further promoting infiltrations [137]. The deployment of a level-spreader vegetative filter strip system can be referred to elsewhere [138]. This system has to be designed upon high permeable soils for infiltrating stormwater effectively [139]. The level spreader slows down rainwater flow rate for promoting infiltration, reducing runoff volume and attenuating peak flow [140]. Hunt et al. [141] monitored the hydrological performance of a level spreader-vegetated filter strip. It is found that the strip can eliminate outflow from 20 of 23 rain events and that the total runoff volume reduction is $85 \%$. Similarly, Line and Hunt [142] monitored a level spreader-grass filter strip over 14 storm events and found that the runoff volume is cut by $49 \%$ and that the peak flow is attenuated by $23 \%$. In some cases, peak flows were reduced by an order of magnitude [140]. However, as the rainfall depth increases, the peak flow cannot further decrease as the underlying soil became saturated.

\subsubsection{Swales}

Swales, also called bioswales, bio-retention basins, and ecology ditch, are excavated lands backfilled with a vegetated surface layer and a filter intermediate layer upon natural soils to pond rainwater for subsequent infiltration (Figure 9) [143]. The filler in the excavated bowl is the storage zone to retain rainwater [144]. Water passing through the filler infiltrates to the subsoils. In the areas with low-permeable soils, underdrained pipes are buried in the swales to divert the excessive water to nearby sewer pipes [145]. At the areas where the groundwater stays shallow, a groundwater mound usually forms under the swale, reducing the infiltration rate [146,147]. In this circumstance, perforated pipes are usually buried at the bottom of the swale to divert excessive water to nearby waterways. Abida and Sabourin [148] found that total seasonal discharge from a swale with underdrain perforated pipes is 2.7-13 times lower than the discharge from a swale without underdrain. A swale with a thick filter intermediate layer performs better in peak-flow attenuation and runoff reduction. The retention and infiltration of the filter layer should be optimized to retain water and to avoid overflow simultaneously [149]. While a swale can fully intercept rainwater during small or medium rainfall, overflow is inevitable under heavy and continual rainfall events [71]. The amount of overflow decreases when the internal water storage zone increases [144]. This amount also depends on the rainfall duration and the rainfall intensity and on the drainable capacity of the underlying soils [150]. 


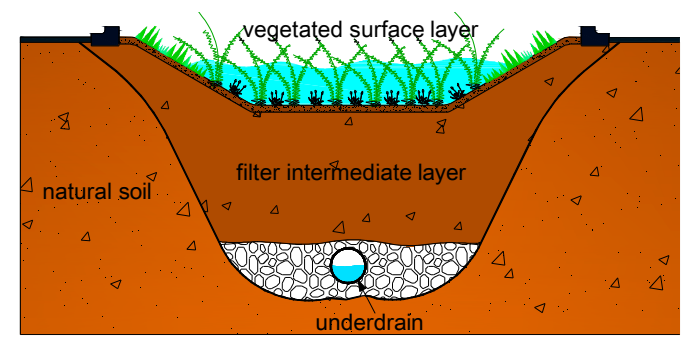

Figure 9. A swale is a depressed vegetated layer over a filter intermediate layer upon natural permeable soils to pond rainwater for promoting infiltration.

The clog of a swale is deleterious to the hydrological performance of the swale. By monitoring the hydraulic conductivity of stormwater biofilters, Le Coustumer et al. [151] found that a biofilter with an initial low conductivity decreases negligibly over time but that with an initial high conductivity drops greatly. The decreases of the conductivity over time are likely caused by sediments depositing at the soil-air interface and by the hydraulic compaction (consolidation) of the growth media. Unlike non-vegetated infiltrated trenches which tend to be clogged permanently due to the settlement of fine particle carried by rainwater [151], bio-retention filter is less likely being fully clogged because vegetated roots provide conduits for water infiltration [152]. Similar findings are reported by Dechesne et al. [153], which found a swale still has good infiltration after 20-year operations. The risk of clogging can be reduced by installing a check dams on the upstream of the swale to slow the velocity of the runoff and to allow sediments to settle [154].

\section{Underground Techniques}

\subsection{Soakaways}

Soakaways are small-scale underground chambers filled with gravel and stones, which detain rainwater for subsequent infiltration to the local soils [155]. With respect to water detention and infiltration, soakaways are similar to infiltration trenches. However, a soakaway is buried underground, which does not sacrifice lands for construction. Soakaways are built locally in a rain garden or backyard, where water from the downspouts and from other sealed surfaces can enter the soakaway via gravitational flow (Figure 10) [156]. A soakaway is often combined with a pipe to lead excessive inflow water to the local sewers for avoiding flooding during extreme rainfall. By slowly releasing the detained rainwater to the local soils, a soakaway reduces local runoff volume and attenuates the peak flow. As soakaways do not sacrifice land uses, they are often recommended to high-density urbanized areas.

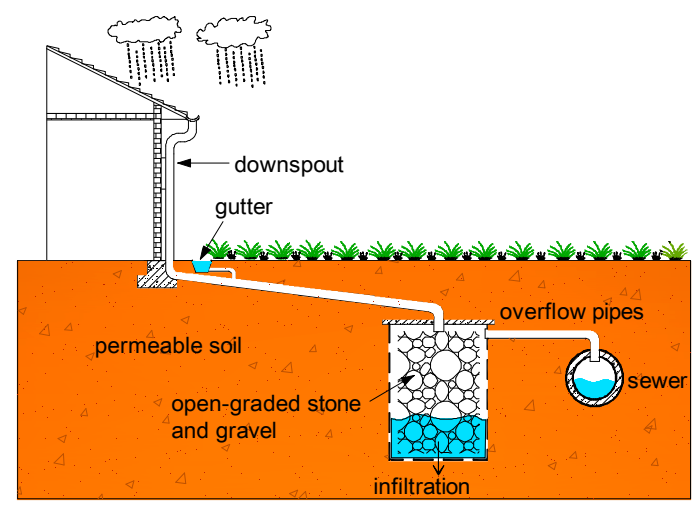

Figure 10. A soakaway is a small-scale underground cell filled with gravel and stones to store rainwater for infiltration. 
However, there are some constraints on the use of a soakaway. First, a soakaway must be constructed in a permeable soil for timely draining the detained rainwater before the next heavy storm events. Second, groundwater is important to consider in the implementation of soakaways. In the area groundwater situates shallow, there is a groundwater mound under the soakaway, which may not evacuate the detained rainwater before the next storm event $[157,158]$. In this situation, pipes are usually placed at the top of the soakaway to carry off the excessive water [159]. Currently, most of researches are focusing on modeling the hydrological performance of soakaways, but few report the long-term performance of soakaways. The long-term retention and detention of water in soakaways is simulated by assuming that the drainage of the soakaways is changed during its lifetime $[159,160]$. However, during the lifetime of a soakaway, fine particles carried by rainwater would settle on the interface between permeable soils and gravel filters, potentially reducing the infiltration capacity of the soakaways. In addition, as most soils in urbanized areas are compacted and low-permeable, there are very few places for construction soakaways for rainwater infiltration.

\subsection{Underground Tanks}

Different from rain barrels, rainwater tanks are installed to harvest rainwater runoff from roofs and other sealed surfaces for subsequent non-potable water uses [161,162]. Depending on the source of the runoff, the tank can be placed on the ground surface or underground as long as the rainwater can enter the tank via gravitational flow. If the tank is placed on the ground surface, lands must be sacrificed [163] and the overflow from the tank can be connected to a rain garden for infiltration. This further sacrifices the land use so it is preferred to bury the tank underground and to convey the overflow from the tank to the local sewers (Figure 11).

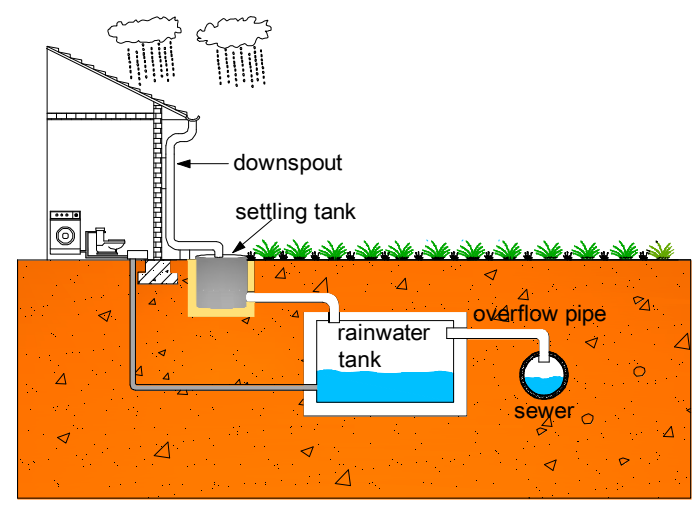

Figure 11. An underground tank stores rainwater from the above sealed surfaces for subsequent non-potable uses. Overflow from the tank is led to local sewers.

Similar to rain barrels, the effectiveness of using a rainwater tank to mitigate urban flooding depends on the tank's size, the homeowners' participation, and rain depth $[164,165]$. For instance, Khastagir and Jayasuriya [166] found that a $100 \mathrm{~m}^{2}$ impervious roof with a $3 \mathrm{~kL}$ tank for harvesting water for toilet flushing, garden irrigation, and laundry demand reduces runoff volume about $70 \%$. The runoff reduction volume is also influenced by the use of the harvested rainwater [167]. If the tank is built to harvest rainwater for multi-end water uses, the tank would be more effective than that for a single use $[168,169]$. In addition, if the use of water during the intermission between two adjacent heavy rainfall cannot empty the tank, the tank would fail to reset for storing rainwater in the next heavy rainfall [170]. While a community accept to install rainwater tanks for rainwater use, it is less interested in maintaining rainwater tanks routinely [171]. At heavy rain, a rainwater tank has limited capacity to reduce the peak flow of the runoff [172]. Therefore, the adoption of rainwater tanks is challenged both by the tank's size, homeowner participation, and the rain depth.

A rainwater tank is used indispensably with flow regulators, pipes, faucets, a pump, and other devices [173]. Additional energy must be continuously supplied for lifting the rainwater in the tank 
to the user ends. This lift involves both capital investments and maintenance costs. Gowland and Younos [174] studied the feasibility of rainwater-harvesting tanks and found that the pumping cost is the greatest capital investment. They found that the installation of a rainwater tank can be re-paid by harvesting rainwater for non-potable water uses [162]. The payback period is jointly affected by the tank's size [175], the water usage [176], the local water price [177], the locations [178], and the whole life cost [179].

\section{Discussion}

While some mainstream techniques mentioned above are used in combination for further reducing the runoff volume and attenuating peak flow, a technique that is used in combination with others plays the same role as it works individually $[180,181]$. Combinations of these techniques are thus not discussed further. While current mainstream stormwater-management techniques can mitigate the urban flooding caused by small rainfalls, in most cases they fail do so for a heavy rainfall. During heavy rainfall, runoff from unsealed and sealed surfaces superimposes, causing the peak flow to overwhelm the carrying capacity of the local sewers. While some of these techniques can be implemented during the retrofit process, the implementation of the rain garden, vegetative filter strip, bioswale would sacrifice lands and tense the land use problems in urbanized areas. Other techniques such as permeable pavements are suitable only to low-volume light-duty paving areas such as parking lots and pedestrian lanes. Therefore, as urban flooding takes place at heavy rainfall events only, current technologies do little to mitigate urban flooding.

To find a solution for urban flooding, we must understand that runoffs from sealed and unsealed surfaces merge together and make the superimposed peak flow overwhelm the carrying capacity of local sewers (Figure 12a). For instance, in Figure 12a, the runoff from catchments of B, C, and D merge together, generating a peak flow (hydrograph A) that is substantially greater than the carrying-capacity of the local sewer. To void the peak flow exceeding the carrying capacity of local sewers, the peak flow must be attenuated substantially [182]. Assuming the hydrographs can be simplified to a triangle and the area of the triangle represents the total runoff [5], the peak flow must be attenuated by extending the discharge duration proportionally (Figure 12b). That is, if the peak flow is intended to be attenuated $50 \%$, the discharge duration must be increased twice. While green roofs, permeable pavements, bioswales, and other techniques can extend the discharge duration to some extent, they cannot prolong the discharge duration dramatically, especially during a heavy rainfall. A soakaways can detain a sizeable of water volume and discharge it later to the local soils [157,160], but the detained volume of a soakaway is small because water is mainly stored in the pore of the soakaway's filler. In addition, the discharge rate from a soakaway is uncontrollable; a fast discharge rate may unlawfully transfer the flooding problems to low-lying locations [183]. Therefore, future research should focus on the development of novel, discharge-controllable facilities to attenuate the peak flow of urban runoff by extending the discharge duration. These facilities must reset their capacity of peak-flow attenuation automatically before the next heavy rainfall.

As an example, Qin et al. [182] proposed a leak tank that can temperately detain rainwater and then slowly release it to the nearby sewers. A schematic of the leak tank can be seen Figure 13. Rainwater is routed to the tank though a large pipe that is set above the tank, while the outlet orifice is set at the side of the tank and at a height above the tank's bottom to avoid being clogged by debris. Rainwater from sealed pavements, rooftops, or other surfaces can be routed to the tank via gravitational flow without directly entering the local sewers. When the tank is empty, rainwater is detained in the tank. When the water in the tank levels above the leak orifice, a portion of inflow remains detained in the tank while the remaining surplus water drains from the leak orifice. After the inflow ceases, the water above the leak orifice continuously releases until the water in the tank levels with the orifice. Finally, the tank is re-set to detain rainwater inflow at the subsequent rain event without manual interventions. Assuming a catchment area of $100 \mathrm{~m}^{2}$, and runoff coefficient of 0.8 , a tank base's area of $2 \mathrm{~m}$, and a tank's height of $1.5 \mathrm{~m}$ and assuming a $10 \mathrm{~cm}$ depth of rain whose instantaneous rainfall intensity is 
a gamma distribution with a duration of 0.25 hour, Qin et al. [182] found that the peak flow can be attenuated about $45 \%$ and the peak flow is retard about a quarter of hour (Figure 14). As a $10 \mathrm{~cm}$ rain depth and a 0.25 hour rain duration can be deemed as an extremely heavy rain, it is believed that the urban flooding can be greatly mitigated if a serial of leak tanks with proper sizes is designed to the right places to detain rainwater on the source. While such tanks seem promising, their long-term hydrological performances are still awaiting further studies.
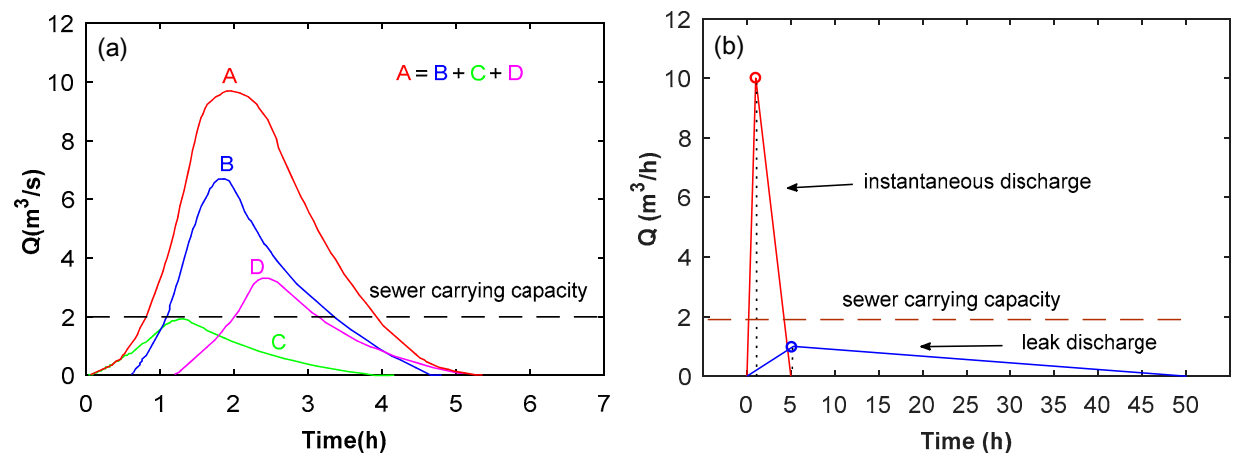

Figure 12. Attenuating the peak flow should be done by extending the discharge time proportionally. (a) The runoff from catchments of B, C, and D merge together, resulting a greater runoff A (b) Peak flow of hydrographs are dwarfed by extending the discharge duration [182].

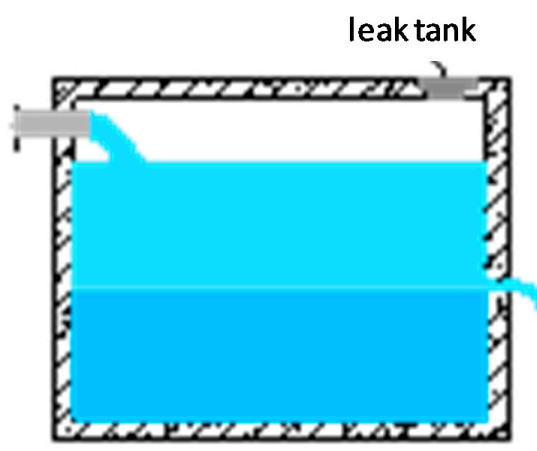

Figure 13. A buffer tank that detains rainwater temperately and releases it slowly at the side of the tank. The release orifice is set some elevation above the bottom of the tank to avoid clog.

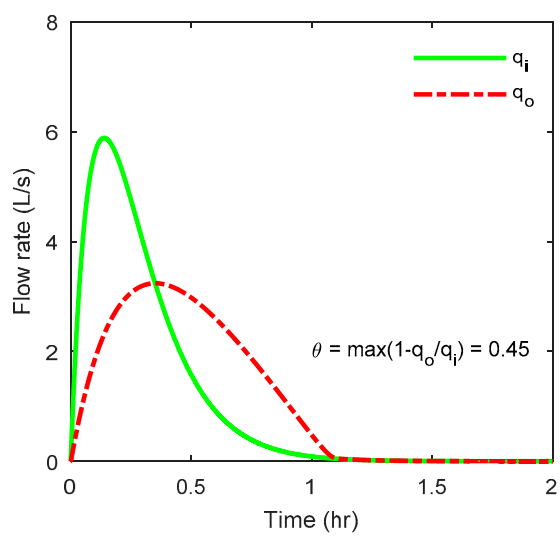

Figure 14. A leak tank attenuates the peak flow of runoff and retards the peak flow effectively. The simulation assumes a catchment area of $100 \mathrm{~m}^{2}$, a runoff coefficient of 0.8 , a tank base's area of $2 \mathrm{~m}$, and a tank's height of $1.5 \mathrm{~m}$ and assuming a $10 \mathrm{~cm}$ depth of rain whose rainfall intensity is a gamma distribution. Rain duration is 0.25 hour. $\mathrm{q}_{i}=$ inflow; $\mathrm{q}_{\mathrm{o}}=$ outflow; $\theta=$ peak flow attenuation rate. 


\section{Conclusions}

This paper briefly reviews mainstream techniques for urban flooding mitigation. Techniques are categorized into aboveground ones, including vegetated and non-vegetated roofs; ground-surface ones, including permeable pavements, water-retaining pavements, trees, bio-retention, infiltration trenches; and underground ones, including soakaways and other underground water storage units. Water barrels and water tanks are used to harvest rainwater for non-potable uses but they must be frequently emptied by homeowners to continually reset them. Vegetated and non-vegetated roofs, permeable pavements, water-retaining pavements, trees, bio-retention, and infiltration trenches have great ability to retain and detain rainwater in case of a small rain. Clogs of permeable pavements, infiltration trenches, and soakaways degrade their hydrological performance, which can be restored by frequent maintenance. Techniques like green roofs, urban trees, swales, and bio-retention can maintain good infiltration over time because roots of vegetated species, urban trees, swale grass, bio-retention plants loosen the growth media for water infiltration.

While mainstream techniques effectively retain, store and/or infiltrate rainwater during small rainfalls, they lead to great overflows during heavy rain. As urban flooding takes place when the overflows from different catchments superimpose to a degree that exceeds the carrying capacity of local sewer pipes, current mainstream techniques are insufficient to mitigate urban flooding. To mitigate urban flooding, in case of a heavy rainfall, the peak flow must be attenuated substantially and the discharge duration must be extended proportionally. New studies shall focus on the development of novel, discharge-controllable devices that can attenuate the peak flow in case of heavy rainfalls by extending the duration of the runoff discharge. Leak tanks that can detain rainwater at the source and discharge it slowly for a longer duration than the rain duration are promising options to attenuate the peak flow of urban runoff and to reset tanks automatically. Further studies are necessary to understand the long-term hydrological performance of the leak tanks.

Author Contributions: Y.Q. prepared and wrote all the content of the manuscript. All authors have read and agreed to the published version of the manuscript.

Funding: This work is supported by the high-level innovation team and outstanding scholar program in Guangxi colleges (granted to Y. Q.) and by the Science Foundation of Guangxi (Grant no. 2018GXNSFAA294070, no. 2018GXNSFDA138009).

Conflicts of Interest: The author declares no conflict of interest.

\section{References}

1. Recanatesi, F.; Petroselli, A.; Ripa, M.N.; Leone, A. Assessment of stormwater runoff management practices and BMPs under soil sealing: A study case in a peri-urban watershed of the metropolitan area of Rome (Italy). J. Environ. Manag. 2017, 201, 6-18. [CrossRef] [PubMed]

2. Xu, D.; Ouyang, Z.; Wu, T.; Han, B. Dynamic Trends of Urban Flooding Mitigation Services in Shenzhen, China. Sustainability 2020, 12, 4799. [CrossRef]

3. Gregory, J.H.; Dukes, M.D.; Jones, P.H.; Miller, G.L. Effect of urban soil compaction on infiltration rate. J. Soil Water Conserv. 2006, 61, 117-124.

4. Yang, Q.; Zhang, S.; Dai, Q.; Yao, R. Assessment of Community Vulnerability to Different Types of Urban Floods: A Case for Lishui City, China. Sustainability 2020, 12, 7865. [CrossRef]

5. Ferguson, B.K. Storm-Water Infiltration for Peak-Flow Control. J. Irrig. Drain. Eng. 1995, 121, 463-466. [CrossRef]

6. Mitchell, V.G. Applying Integrated Urban Water Management Concepts: A Review of Australian Experience. Environ. Manag. 2006, 37, 589-605. [CrossRef]

7. Wong, T.H.F. Water sensitive urban design — the journey thus far. Australasian. J. Water Resour. 2006, 10, 213-222.

8. Eckart, K.; McPhee, Z.; Bolisetti, T. Performance and implementation of low impact development-A review. Sci. Total Environ. 2017, 607-608, 413-432. [CrossRef] 
9. Lim, H.S.; Lu, X.X. Sustainable urban stormwater management in the tropics: An evaluation of Singapore's ABC Waters Program. J. Hydrol. 2016, 538, 842-862. [CrossRef]

10. Wang, H.; Mei, C.; Liu, J.; Shao, W. A new strategy for integrated urban water management in China: Sponge city. Sci. China Technol. Sci. 2018, 61,317-329. [CrossRef]

11. Zhou, Q. A Review of Sustainable Urban Drainage Systems Considering the Climate Change and Urbanization Impacts. Water 2014, 6, 976. [CrossRef]

12. Miles, B.; Band, L.E. Green infrastructure stormwater management at the watershed scale: Urban variable source area and watershed capacitance. Hydrol. Process. 2015, 29, 2268-2274. [CrossRef]

13. Qiao, X.-J.; Liao, K.-H.; Randrup, T.B. Sustainable stormwater management: A qualitative case study of the Sponge Cities initiative in China. Sustain. Cities Soc. 2020, 53, 101963. [CrossRef]

14. Pratt, C.J. A Review of Source Control of Urban Stormwater Runoff. Water Environ. J. 1995, 9, 132-139. [CrossRef]

15. Dietz, M.E. Low Impact Development Practices: A Review of Current Research and Recommendations for Future Directions. Water Air Soil Pollut. 2007, 186, 351-363. [CrossRef]

16. Ahiablame, L.M.; Engel, B.A.; Chaubey, I. Effectiveness of Low Impact Development Practices: Literature Review and Suggestions for Future Research. Water Air Soil Pollut. 2012, 223, 4253-4273. [CrossRef]

17. Niachou, A.; Papakonstantinou, K.; Santamouris, M.; Tsangrassoulis, A.; Mihalakakou, G. Analysis of the green roof thermal properties and investigation of its energy performance. Energy Build. 2001, 33, 719-729. [CrossRef]

18. Madre, F.; Vergnes, A.; Machon, N.; Clergeau, P. A comparison of 3 types of green roof as habitats for arthropods. Ecol. Eng. 2013, 57, 109-117. [CrossRef]

19. Jungels, J.; Rakow, D.A.; Allred, S.B.; Skelly, S.M. Attitudes and aesthetic reactions toward green roofs in the Northeastern United States. Landsc. Urban Plan. 2013, 117, 13-21. [CrossRef]

20. Susca, T.; Gaffin, S.R.; Dell'Osso, G.R. Positive effects of vegetation: Urban heat island and green roofs. Environ. Pollut. 2011, 159, 2119-2126. [CrossRef]

21. Getter, K.L.; Rowe, D.B.; Robertson, G.P.; Cregg, B.M.; Andresen, J.A. Carbon Sequestration Potential of Extensive Green Roofs. Environ. Sci. Technol. 2009, 43, 7564-7570. [CrossRef] [PubMed]

22. Oberndorfer, E.; Lundholm, J.; Bass, B.; Coffman, R.R.; Doshi, H.; Dunnett, N.; Gaffin, S.; Köhler, M.; Liu, K.K.Y.; Rowe, B. Green Roofs as Urban Ecosystems: Ecological Structures, Functions, and Services. BioScience 2007, 57, 823-833. [CrossRef]

23. Berardi, U.; GhaffarianHoseini, A.; GhaffarianHoseini, A. State-of-the-art analysis of the environmental benefits of green roofs. Appl. Energy 2014, 115, 411-428. [CrossRef]

24. Hutchinson, D.; Abrams, P.; Retzlaff, R.; Liptan, T. Stormwater Monitoring Two Ecoroofs in Portland, Oregon, USA; Int. Conf. on Greening Rooftops for Sustainable Communities: Chicago, IL, USA, 2003; pp. 372-389.

25. Li, S.-x.; Qin, H.-p.; Peng, Y.-n.; Khu, S.T. Modelling the combined effects of runoff reduction and increase in evapotranspiration for green roofs with a storage layer. Ecol. Eng. 2019, 127, 302-311. [CrossRef]

26. Lee, J.Y.; Lee, M.J.; Han, M. A pilot study to evaluate runoff quantity from green roofs. J. Environ. Manag. 2015, 152, 171-176. [CrossRef]

27. Spolek, G. Performance monitoring of three ecoroofs in Portland, Oregon. Urban Ecosyst. 2008, 11, 349-359. [CrossRef]

28. Zhang, Q.; Miao, L.; Wang, X.; Liu, D.; Zhu, L.; Zhou, B.; Sun, J.; Liu, J. The capacity of greening roof to reduce stormwater runoff and pollution. Landsc. Urban Plan. 2015, 144, 142-150. [CrossRef]

29. Palermo, S.A.; Turco, M.; Principato, F.; Piro, P. Hydrological Effectiveness of an Extensive Green Roof in Mediterranean Climate. Water 2019, 11. [CrossRef]

30. DeNardo, J.C.; Jarrett, A.R.; Manbeck, H.B.; Beattie, D.J.; Berghage, R.D. Stormwater mitigation and surface temperature reduction by green roofs. Trans. ASAE 2005, 48, 1491-1496. [CrossRef]

31. Gregoire, B.G.; Clausen, J.C. Effect of a modular extensive green roof on stormwater runoff and water quality. Ecol. Eng. 2011, 37, 963-969. [CrossRef]

32. Talebi, A.; Bagg, S.; Sleep, B.E.; O'Carroll, D.M. Water retention performance of green roof technology: A comparison of canadian climates. Ecol. Eng. 2019, 126, 1-15. [CrossRef]

33. Vanuytrecht, E.; Van Mechelen, C.; Van Meerbeek, K.; Willems, P.; Hermy, M.; Raes, D. Runoff and vegetation stress of green roofs under different climate change scenarios. Landsc. Urban Plan. 2014, 122, 68-77. [CrossRef] 
34. Dunnett, N.; Nagase, A.; Booth, R.; Grime, P. Influence of vegetation composition on runoff in two simulated green roof experiments. Urban Ecosyst. 2008, 11, 385-398. [CrossRef]

35. Nagase, A.; Dunnett, N. Amount of water runoff from different vegetation types on extensive green roofs: Effects of plant species, diversity and plant structure. Landsc. Urban Plan. 2012, 104, 356-363. [CrossRef]

36. Buccola, N.; Spolek, G. A Pilot-Scale Evaluation of Greenroof Runoff Retention, Detention, and Quality. Water Air Soil Pollut. 2011, 216, 83-92. [CrossRef]

37. Mentens, J.; Raes, D.; Hermy, M. Green roofs as a tool for solving the rainwater runoff problem in the urbanized 21st century? Landsc. Urban Plan. 2006, 77, 217-226. [CrossRef]

38. Villarreal, E.L.; Bengtsson, L. Response of a Sedum green-roof to individual rain events. Ecol. Eng. 2005, 25, 1-7. [CrossRef]

39. VanWoert, N.D.; Rowe, D.B.; Andresen, J.A.; Rugh, C.L.; Fernandez, R.T.; Xiao, L. Green Roof Stormwater Retention: Effect of Roof Surface, Slope, and Media Depth. J. Environ. Qual. 2005, 34, 1036-1044. [CrossRef]

40. Mangangka, I.R.; Liu, A.; Egodawatta, P.; Goonetilleke, A. Performance characterisation of a stormwater treatment bioretention basin. J. Environ. Manag. 2015, 150, 173-178. [CrossRef]

41. Carson, T.B.; Marasco, D.E.; Culligan, P.J.; McGillis, W.R. Hydrological performance of extensive green roofs in New York City: Observations and multi-year modeling of three full-scale systems. Environ. Res. Lett. 2013, 8, 024036. [CrossRef]

42. Bliss, D.J.; Neufeld, R.D.; Ries, R.J. Storm Water Runoff Mitigation Using a Green Roof. Environ. Eng. Sci. 2009, 26, 407-417. [CrossRef]

43. Schroll, E.; Lambrinos, J.; Righetti, T.; Sandrock, D. The role of vegetation in regulating stormwater runoff from green roofs in a winter rainfall climate. Ecol. Eng. 2011, 37, 595-600. [CrossRef]

44. Fassman-Beck, E.; Voyde, E.; Simcock, R.; Hong, Y.S. 4 Living roofs in 3 locations: Does configuration affect runoff mitigation? J. hydrol. 2013, 490, 11-20. [CrossRef]

45. Czemiel Berndtsson, J. Green roof performance towards management of runoff water quantity and quality: A review. Ecol. Eng. 2010, 36, 351-360. [CrossRef]

46. Liu, X.; Chui, T.F.M. Evaluation of Green Roof Performance in Mitigating the Impact of Extreme Storms. Water 2019, 11, 815. [CrossRef]

47. Getter, K.L.; Rowe, D.B. The Role of Extensive Green Roofs in Sustainable Development. HortScience 2006, 41, 1276-1285. [CrossRef]

48. Carter, T.L.; Rasmussen, T.C. Hydrologic behavior of vegetated roofs. JAWRA J. Am. Water Resour. Assoc. 2006, 42, 1261-1274. [CrossRef]

49. Teemusk, A.; Mander, Ü. Rainwater runoff quantity and quality performance from a greenroof: The effects of short-term events. Ecol. Eng. 2007, 30, 271-277. [CrossRef]

50. Trinh, D.H.; Chui, T.F.M. Assessing the hydrologic restoration of an urbanized area via an integrated distributed hydrological model. Hydrol. Earth Syst. Sci. 2013, 17, 4789-4801. [CrossRef]

51. Stovin, V.; Vesuviano, G.; Kasmin, H. The hydrological performance of a green roof test bed under UK climatic conditions. J. Hydrol. 2012, 414-415, 148-161. [CrossRef]

52. Ercolani, G.; Chiaradia, E.A.; Gandolfi, C.; Castelli, F.; Masseroni, D. Evaluating performances of green roofs for stormwater runoff mitigation in a high flood risk urban catchment. J. Hydrol. 2018, 566, 830-845. [CrossRef]

53. Carter, T.; Jackson, C.R. Vegetated roofs for stormwater management at multiple spatial scales. Landsc. Urban Plan. 2007, 80, 84-94. [CrossRef]

54. DeNardo, J.C.; Jarrett, A.R.; Manbeck, H.B.; Beattie, D.J. Stormwater Detention and Retention Abilities of Green Roofs. In Proceedings of the World Water and Environmental Resources Congress, Philadelphia, PA, USA, 23-26 June 2003; pp. 1639-1645.

55. Lee, J.Y.; Moon, H.J.; Kim, T.I.; Kim, H.W.; Han, M.Y. Quantitative analysis on the urban flood mitigation effect by the extensive green roof system. Environ. Pollut. 2013, 181, 257-261. [CrossRef] [PubMed]

56. Whittinghill, L.J.; Rowe, D.B.; Andresen, J.A.; Cregg, B.M. Comparison of stormwater runoff from sedum, native prairie, and vegetable producing green roofs. Urban Ecosyst. 2015, 18, 13-29. [CrossRef]

57. Voyde, E.; Fassman, E.; Simcock, R. Hydrology of an extensive living roof under sub-tropical climate conditions in Auckland, New Zealand. J. Hydrol. 2010, 394, 384-395. [CrossRef]

58. Monterusso, M.A.; Rowe, D.B.; Rugh, C.L.; Russell, D.K. Runoff Water Quantity and Quality from Green Roof Systems; International Society for Horticultural Science (ISHS): Leuven, Belgium, 2004; pp. 369-376. 
59. Volder, A.; Dvorak, B. Event size, substrate water content and vegetation affect storm water retention efficiency of an un-irrigated extensive green roof system in Central Texas. Sustain. Cities Soc. 2014, 10, 59-64. [CrossRef]

60. Speak, A.F.; Rothwell, J.J.; Lindley, S.J.; Smith, C.L. Rainwater runoff retention on an aged intensive green roof. Sci. Total Environ. 2013, 461-462, 28-38. [CrossRef]

61. Kolb, W. Good reasons for roof planting-Green roofs and rainwater. In International Conference on Urban Horticulture; Junge-Berberovic, R., Baechtiger, J.-B., Simpson, W.J., Eds.; International Society for Horticultural Science (ISHS): Waedenswil, Switzerland, 2004; pp. 295-300.

62. Razzaghmanesh, M.; Beecham, S. The hydrological behaviour of extensive and intensive green roofs in a dry climate. Sci. Total Environ. 2014, 499, 284-296. [CrossRef]

63. Shafique, M.; Luo, X. Comparison Study of Green Roof, Blue Roof, Green Blue Roof for Storm Water Management: A Review. In Proceedings of the International Conference on Construction and Real Estate Management (ICCREM), Banff, AB, Canada, 21-24 May 2019; pp. 475-482.

64. Carpenter, D.; Kaluvakolanu, P. Effect of Roof Surface Type on Storm-Water Runoff from Full-Scale Roofs in a Temperate Climate. J. Irrig. Drain. Eng. 2011, 137, 161-169. [CrossRef]

65. Mullaney, J.; Lucke, T. Practical Review of Pervious Pavement Designs. CLEAN Soil Air Water 2014, 42, 111-124. [CrossRef]

66. Sañudo-Fontaneda, L.A.; Charlesworth, S.M.; Castro-Fresno, D.; Andres-Valeri, V.C.A.; Rodriguez-Hernandez, J. Water quality and quantity assessment of pervious pavements performance in experimental car park areas. Water Sci. Technol. 2014, 69, 1526-1533. [CrossRef] [PubMed]

67. Qin, Y. A review on the development of cool pavements to mitigate urban heat island effect. Renew. Sustain. Energy Rev. 2015, 52, 445-459. [CrossRef]

68. Cheng, Y.-Y.; Lo, S.-L.; Ho, C.-C.; Lin, J.-Y.; Yu, S. Field Testing of Porous Pavement Performance on Runoff and Temperature Control in Taipei City. Water 2019, 11, 2635. [CrossRef]

69. Park, S.B.; Lee, B.J.; Lee, J.; Jang, Y.I. A study on the seawater purification characteristics of water-permeable concrete using recycled aggregate. Resour. Conserv. Recycl. 2010, 54, 658-665. [CrossRef]

70. Andersen, C.T.; Foster, I.D.L.; Pratt, C.J. The role of urban surfaces (permeable pavements) in regulating drainage and evaporation: Development of a laboratory simulation experiment. Hydrol. process. 1999, 13, 597-609. [CrossRef]

71. Gülbaz, S.; Kazezyılmaz-Alhan, C.M. Experimental Investigation on Hydrologic Performance of LID with Rainfall-Watershed-Bioretention System. J. Hydrol. Eng. 2017, 22, D4016003. [CrossRef]

72. Li, H.; Harvey, J.T.; Holland, T.J.; Kayhanian, M. The use of reflective and permeable pavements as a potential practice for heat island mitigation and stormwater management. Environ. Res. Lett. 2013, 8, 015023. [CrossRef]

73. Jiao, L.; Ni, F.; Yang, J. Long-term field performance of porous asphalt pavement in China AU-Yu, Bin. Road Mater. Pavement Des. 2015, 16, 214-226.

74. Imran, H.M.; Akib, S.; Karim, M.R. Permeable pavement and stormwater management systems: A review. Environ. Technol. 2013, 34, 2649-2656. [CrossRef]

75. Park, J.; Park, J.; Cheon, J.; Lee, J.; Shin, H. Analysis of Infiltrating Water Characteristics of Permeable Pavements in a Parking Lot at Full Scale. Water 2020, 12, 2081. [CrossRef]

76. Chai, L.; Kayhanian, M.; Givens, B.; Harvey, J.; Jones, D. Hydraulic Performance of Fully Permeable Highway Shoulder for Storm Water Runoff Management. J. Environ. Eng. 2012, 138, 711-722. [CrossRef]

77. Dreelin, E.A.; Fowler, L.; Ronald Carroll, C. A test of porous pavement effectiveness on clay soils during natural storm events. Water Res. 2006, 40, 799-805. [CrossRef] [PubMed]

78. Watanabe, S. Study on storm water control by permeable pavement and infiltration pipes. Water Sci. Technol. 1995, 32, 25-32. [CrossRef]

79. Collins, K.; Hunt, W.; Hathaway, J. Hydrologic Comparison of Four Types of Permeable Pavement and Standard Asphalt in Eastern North Carolina. J. Hydrol. Eng. 2008, 13, 1146-1157. [CrossRef]

80. Alam, T.; Mahmoud, A.; Jones, K.D.; Bezares-Cruz, J.C.; Guerrero, J. A Comparison of Three Types of Permeable Pavements for Urban Runoff Mitigation in the Semi-Arid South Texas, U.S.A. Water 2019, 11, 1992. [CrossRef] 
81. Rodriguez-Hernandez, J.; Andrés-Valeri Valerio, C.; Ascorbe-Salcedo, A.; Castro-Fresno, D. Laboratory Study on the Stormwater Retention and Runoff Attenuation Capacity of Four Permeable Pavements. J. Environ. Eng. 2016, 142, 04015068. [CrossRef]

82. Zachary Bean, E.; Frederick Hunt, W.; Alan Bidelspach, D. Evaluation of Four Permeable Pavement Sites in Eastern North Carolina for Runoff Reduction and Water Quality Impacts. J. Irrig. Drain. Eng. 2007, 133, 583-592. [CrossRef]

83. Gomez-Ullate, E.; Castillo-Lopez, E.; Castro-Fresno, D.; Bayon, J.R. Analysis and Contrast of Different Pervious Pavements for Management of Storm-Water in a Parking Area in Northern Spain. Water Resour. Manag. 2011, 25, 1525-1535. [CrossRef]

84. Brattebo, B.O.; Booth, D.B. Long-term stormwater quantity and quality performance of permeable pavement systems. Water Res. 2003, 37, 4369-4376. [CrossRef]

85. Fassman, E.; Blackbourn, S. Urban Runoff Mitigation by a Permeable Pavement System over Impermeable Soils. J. Hydrol. Eng. 2010, 15, 475-485. [CrossRef]

86. Haselbach, L.M.; Valavala, S.; Montes, F. Permeability predictions for sand-clogged Portland cement pervious concrete pavement systems. J. Environ. Manag. 2006, 81, 42-49. [CrossRef] [PubMed]

87. Sansalone, J.; Kuang, X.; Ying, G.; Ranieri, V. Filtration and clogging of permeable pavement loaded by urban drainage. Water Res. 2012, 46, 6763-6774. [CrossRef] [PubMed]

88. Bean, E.Z.; Hunt, W.F.; Bidelspach, D.A. Field Survey of Permeable Pavement Surface Infiltration Rates. J. Irrig. Drain. Eng. 2007, 133, 249-255. [CrossRef]

89. Pezzaniti, D.; Beecham, S.; Kandasamy, J. Influence of clogging on the effective life of permeable pavements. Proceedings of the Institution of Civil Engineers. Water Manag. 2009, 162, 1-10. [CrossRef]

90. Chopra, M.; Kakuturu, S.; Ballock, C.; Spence, J.; Wanielista, M. Effect of Rejuvenation Methods on the Infiltration Rates of Pervious Concrete Pavements. J. Hydrol. Eng. 2010, 15, 426-433. [CrossRef]

91. Kia, A.; Wong, H.S.; Cheeseman, C.R. Clogging in permeable concrete: A review. J. Environ. Manag. 2017, 193, 221-233. [CrossRef]

92. Nakayama, T.; Fujita, T. Cooling effect of water-holding pavements made of new materials on water and heat budgets in urban areas. Landsc. Urban Plan. 2010, 96, 57-67. [CrossRef]

93. Katsunori, T.; Kazuya, Y. Road Temperature Mitigation Effect of 'Road Cool', a Water-Retentive Material Using Blast Furnace Slag. JEF GIHO 2008, 19, 28-32.

94. Kinoshita, S.; Yoshida, A.; Okuno, N. Evaporation performance analysis for water-retentive materials, based on outddor heat-bedget and transport properties. J. Heat Isl. Inst. Int. 2012, 7, 222-230.

95. Yamagata, H.; Nasu, M.; Yoshizama, M.; Miyamota, A.; Minamiyama, M. Heat island mitigation using water retentive pavement sprinkled with reclaimed wastewater. Water Sci. Technol. 2008, 57, 763-771. [CrossRef]

96. Qin, Y.; He, Y.; Hiller, J.E.; Mei, G. A new water-retaining paver block for reducing runoff and cooling pavement. J. Clean. Prod. 2018, 199, 948-956. [CrossRef]

97. Bao, T.; Liu, Z.; Zhang, X.; He, Y. A drainable water-retaining paver block for runoff reduction and evaporation cooling. J. Clean. Prod. 2019, 228, 418-424. [CrossRef]

98. Roy, S.; Byrne, J.; Pickering, C. A systematic quantitative review of urban tree benefits, costs, and assessment methods across cities in different climatic zones. Urban For. Urban Green. 2012, 11, 351-363. [CrossRef]

99. Denman, E.C.; May, P.B.; Moore, G.M. The use of trees in urban stormwater management. In The 12th National Street Tree Symposium; Lawry, D., Merrett, B., Eds.; The University of Adelaide: Adelaide, Australia, 2011; pp. 57-66.

100. Song, P.; Kim, G.; Mayer, A.; He, R.; Tian, G. Assessing the Ecosystem Services of Various Types of Urban Green Spaces Based on i-Tree Eco. Sustainability 2020, 12, 1630. [CrossRef]

101. Scharenbroch, B.C.; Morgenroth, J.; Maule, B. Tree Species Suitability to Bioswales and Impact on the Urban Water Budget. J. Environ. Qual. 2016, 45, 199-206. [CrossRef]

102. Roth, B.E.; Slatton, K.C.; Cohen, M.J. On the potential for high-resolution lidar to improve rainfall interception estimates in forest ecosystems. Front. Ecol. Environ. 2007, 5, 421-428. [CrossRef]

103. Van Stan, J.T.; Levia, D.F.; Jenkins, R.B. Forest Canopy Interception Loss Across Temporal Scales: Implications for Urban Greening Initiatives. Prof. Geogr. 2015, 67, 41-51. [CrossRef]

104. Xiao, Q.; McPherson, E.G.; Ustin, S.L.; Grismer, M.E.; Simpson, J.R. Winter rainfall interception by two mature open-grown trees in Davis, California. Hydrol. process. 2000, 14, 763-784. [CrossRef] 
105. Inkiläinen, E.N.M.; McHale, M.R.; Blank, G.B.; James, A.L.; Nikinmaa, E. The role of the residential urban forest in regulating throughfall: A case study in Raleigh, North Carolina, USA. Landsc. Urban Plan. 2013, 119, 91-103. [CrossRef]

106. Xiao, Q.; McPherson, E.G. Rainfall interception by Santa Monica's municipal urban forest. Urban Ecosyst. 2002, 6, 291-302. [CrossRef]

107. Xiao, Q.; McPherson, E.G. Rainfall interception of three trees in Oakland, California. Urban Ecosyst. 2011, 14, 755-769. [CrossRef]

108. Carlyle-Moses, D.E.; Gash, J.H.C. Rainfall Interception Loss by Forest Canopies. In Forest Hydrology and Biogeochemistry: Synthesis of Past Research and Future Directions; Levia, D.F., Carlyle-Moses, D., Tanaka, T., Eds.; Springer: Dordrecht, The Netherlands, 2011; pp. 407-423.

109. Clapp, J.C.; Ryan, H.D.P.; Harper, R.W.; Bloniarz, D.V. Rationale for the increased use of conifers as functional green infrastructure: A literature review and synthesis. Arboric. J. 2014, 36, 161-178. [CrossRef]

110. Armson, D.; Stringer, P.; Ennos, A.R. The effect of street trees and amenity grass on urban surface water runoff in Manchester, UK. Urban For. Urban Green. 2013, 12, 282-286. [CrossRef]

111. Bartens, J.; Day, S.D.; Harris, J.R.; Wynn, T.M.; Dove, J.E. Transpiration and Root Development of Urban Trees in Structural Soil Stormwater Reservoirs. Environ. Manag. 2009, 44, 646-657. [CrossRef] [PubMed]

112. Bartens, J.; Day, S.D.; Harris, J.R.; Dove, J.E.; Wynn, T.M. Can Urban Tree Roots Improve Infiltration through Compacted Subsoils for Stormwater Management? J. Environ. Qual. 2008, 37, 2048-2057. [CrossRef] [PubMed]

113. Stovin, V.R.; Jorgensen, A.; Clayden, A. Street Trees and Stormwater Management. Arboric. J. 2008, 30, 297-310. [CrossRef]

114. Nachshon, U.; Netzer, L.; Livshitz, Y. Land cover properties and rain water harvesting in urban environments. Sustain. Cities Soc. 2016, 27, 398-406. [CrossRef]

115. Jennings, A.A.; Adeel, A.A.; Hopkins, A.; Litofsky, A.L.; Wellstead, S.W. Rain Barrel-Urban Garden Stormwater Management Performance. J. Environ. Eng. 2013, 139, 757-765. [CrossRef]

116. Litofsky, A.L.E.; Jennings, A.A. Evaluating Rain Barrel Storm Water Management Effectiveness across Climatography Zones of the United States. J. Environ. Eng. 2014, 140, 04014009. [CrossRef]

117. Summerville, N.; Sultana, R. Rainwater harvesting potential in a semiarid Southern California city. AWWA Water Sci. 2019, 1, e1123. [CrossRef]

118. Jarden, K.M.; Jefferson, A.J.; Grieser, J.M. Assessing the effects of catchment-scale urban green infrastructure retrofits on hydrograph characteristics. Hydrol. Process. 2013, 30, 1536-1550. [CrossRef]

119. Gao, Y.; Babin, N.; Turner, A.J.; Hoffa, C.R.; Peel, S.; Prokopy, L.S. Understanding urban-suburban adoption and maintenance of rain barrels. Landsc. Urban Plan. 2016, 153, 99-110. [CrossRef]

120. Chahar, B.R.; Graillot, D.; Gaur, S. Storm-Water Management through Infiltration Trenches. J. Irrig. Drain. Eng. 2012, 138, 274-281. [CrossRef]

121. Locatelli, L.; Mark, O.; Mikkelsen, P.S.; Arnbjerg-Nielsen, K.; Wong, T.; Binning, P.J. Determining the extent of groundwater interference on the performance of infiltration trenches. J. Hydrol. 2015, 529, 1360-1372. [CrossRef]

122. Warnaars, E.; Larsen, A.V.; Jacobsen, P.; Mikkelsen, P.S. Hydrologic behaviour of stormwater infiltration trenches in a central urban area during 23/4 years of operation. Water Sci. Technol. 1999, 39, 217-224. [CrossRef]

123. Siriwardene, N.R.; Deletic, A.; Fletcher, T.D. Clogging of stormwater gravel infiltration systems and filters: Insights from a laboratory study. Water Res. 2007, 41, 1433-1440. [CrossRef] [PubMed]

124. Yang, H.; Dick, W.A.; McCoy, E.L.; Phelan, P.L.; Grewal, P.S. Field evaluation of a new biphasic rain garden for stormwater flow management and pollutant removal. Ecol. Eng. 2013, 54, 22-31. [CrossRef]

125. Dunnett, N.; Clayden, A. Rain Gardens: Managing Water Sustainably in the Garden and Designed Landscape; Timber Press, Inc.: Portland, OR, USA, 2007.

126. Amur, A.; Wadzuk, B.; Traver, R. Analyzing the Performance of a Rain Garden over 15 Years: How Predictable Is the Rain Garden's Response? In Proceedings of the International Low Impact Development Conference, Virtual Online. 20-24 July 2020; pp. 151-162.

127. Guo James, C.Y. Cap-Orifice as a Flow Regulator for Rain Garden Design. J. Irrig. Drain. Eng. 2012, 138, 198-202.

128. Guo, J.C.Y.; Luu, T.M. Operation of Cap Orifice in a Rain Garden. J. Hydrol. Eng. 2015, 20, 06015002. [CrossRef] 
129. Dietz, M.E.; Clausen, J.C. A Field Evaluation of Rain Garden Flow and Pollutant Treatment. Water Air Soil Pollut. 2005, 167, 123-138. [CrossRef]

130. Muthanna, T.M.; Viklander, M.; Thorolfsson, S.T. Seasonal climatic effects on the hydrology of a rain garden. Hydrol. process. 2008, 22, 1640-1649. [CrossRef]

131. Yang, H.; Florence, D.C.; McCoy, E.L.; Dick, W.A.; Grewal, P.S. Design and hydraulic characteristics of a field-scale bi-phasic bioretention rain garden system for storm water management. Water Sci. Technol. 2009, 59, 1863-1872. [CrossRef] [PubMed]

132. Autixier, L.; Mailhot, A.; Bolduc, S.; Madoux-Humery, A.-S.; Galarneau, M.; Prévost, M.; Dorner, S. Evaluating rain gardens as a method to reduce the impact of sewer overflows in sources of drinking water. Sci. Total Environ. 2014, 499, 238-247. [CrossRef] [PubMed]

133. Gavrić, S.; Leonhardt, G.; Marsalek, J.; Viklander, M. Processes improving urban stormwater quality in grass swales and filter strips: A review of research findings. Sci. Total Environ. 2019, 669, 431-447. [CrossRef] [PubMed]

134. Abu-Zreig, M.; Rudra, R.P.; Lalonde, M.N.; Whiteley, H.R.; Kaushik, N.K. Experimental investigation of runoff reduction and sediment removal by vegetated filter strips. Hydrol. process. 2004, 18, 2029-2037. [CrossRef]

135. Otto, S.; Vianello, M.; Infantino, A.; Zanin, G.; Di Guardo, A. Effect of a full-grown vegetative filter strip on herbicide runoff: Maintaining of filter capacity over time. Chemosphere 2008, 71, 74-82. [CrossRef] [PubMed]

136. Saleh, I.; Kavian, A.; Habibnezhad Roushan, M.; Jafarian, Z. The efficiency of vegetative buffer strips in runoff quality and quantity control. Int. J. Environ. Sci. Technol. 2018, 15, 811-820. [CrossRef]

137. Brodie, I. Application of level spreader grass filter strips in south east Queensland, Australia for discharge reduction and passive irrigation. In Proceedings of the 12th International Conference on Urban Drainage (ICUD 2011), Porto Alegre, Brazil, 11-16 September 2011; pp. 1-10.

138. Winston, R.J.; Hunt, W.F.; Osmond, D.L.; Lord, W.G.; Woodward, M.D. Field Evaluation of Four Level Spreader-Vegetative Filter Strips to Improve Urban Storm-Water Quality. J. Irrig. Drain. Eng. 2011, 137, 170-182. [CrossRef]

139. Hathaway, J.M.; Hunt, W.F. Field Evaluation of Level Spreaders in the Piedmont of North Carolina. J. Irrig. Drain. Eng. 2008, 134, 538-542. [CrossRef]

140. Winston, R.J.; Hunt, W.F. Field Evaluation of Level Spreader-Vegetative Filter Strips to Improve Hydrology and Water Quality. In Proceedings of the ASABE 2009-Annual International Meeting (ASABE 2009), Reno, NV, USA, 21-24 June 2009; pp. 1-10.

141. Hunt, W.F.; Hathaway, J.M.; Winston, R.J.; Jadlocki, S.J. Runoff Volume Reduction by a Level Spreader-Vegetated Filter Strip System in Suburban Charlotte, NC. J. Hydrol. Eng. 2010, 15, 499-503. [CrossRef]

142. Line, D.E.; Hunt, W.F. Performance of a Bioretention Area and a Level Spreader-Grass Filter Strip at Two Highway Sites in North Carolina. J. Irrig. Drain. Eng. 2009, 135, 217-224. [CrossRef]

143. Khadka, A.; Kokkonen, T.; Niemi, T.J.; Lähde, E.; Sillanpää, N.; Koivusalo, H. Towards natural water cycle in urban areas: Modelling stormwater management designs. Urban Water J. 2020, 17, 587-597. [CrossRef]

144. Winston, R.J.; Dorsey, J.D.; Hunt, W.F. Quantifying volume reduction and peak flow mitigation for three bioretention cells in clay soils in northeast Ohio. Sci. Total Environ. 2016, 553, 83-95. [CrossRef] [PubMed]

145. Roy-Poirier, A.; Champagne, P.; Filion, Y. Review of Bioretention System Research and Design: Past, Present, and Future. J. Environ. Eng. 2010, 136, 878-889. [CrossRef]

146. Endreny, T.; Collins, V. Implications of bioretention basin spatial arrangements on stormwater recharge and groundwater mounding. Ecol. Eng. 2009, 35, 670-677. [CrossRef]

147. Bouwer, H. Artificial recharge of groundwater: Hydrogeology and engineering. Hydrogeol. J. 2002, 10, 121-142. [CrossRef]

148. Abida, H.; Sabourin, J.F. Grass Swale-Perforated Pipe Systems for Stormwater Management. J. Irrig. Drain. Eng. 2006, 132, 55-63. [CrossRef]

149. Zhang, L.; Lu, Q.; Ding, Y.; Peng, P.; Yao, Y. Design and Performance Simulation of Road Bioretention Media for Sponge Cities. J. Perform. Constr. Facil. 2018, 32, 04018061. [CrossRef]

150. Barber Michael, E.; King Steven, G.; Yonge David, R.; Hathhorn Wade, E. Ecology Ditch: A Best Management Practice for Storm Water Runoff Mitigation. J. Hydrol. Eng. 2003, 8, 111-122. [CrossRef]

151. Le Coustumer, S.; Fletcher, T.D.; Deletic, A.; Barraud, S.; Lewis, J.F. Hydraulic performance of biofilter systems for stormwater management: Influences of design and operation. J. Hydrol. 2009, 376, 16-23. [CrossRef] 
152. Bergman, M.; Hedegaard, M.R.; Petersen, M.F.; Binning, P.; Mark, O.; Mikkelsen, P.S. Evaluation of two stormwater infiltration trenches in central Copenhagen after 15 years of operation. Water Sci. Technol. 2011, 63, 2279-2286. [CrossRef] [PubMed]

153. Dechesne, M.; Barraud, S.; Bardin, J.-P. Experimental Assessment of Stormwater Infiltration Basin Evolution. J. environ. eng. 2005, 131, 1090-1098. [CrossRef]

154. Winston, R.J.; Powell, J.T.; Hunt, W.F. Retrofitting a grass swale with rock check dams: Hydrologic impacts. Urban Water J. 2019, 16, 404-411. [CrossRef]

155. Pratt, C.J. Research and Development in Methods of Soakaway Design. Water Environ. J. 1996, 10, 47-51. [CrossRef]

156. Mylevaganam, S.; Chui, T.F.M.; Hu, J. Multiple Regression Model of a Soak-Away Rain Garden in Singapore. Open J. Model. Simul. 2015, 3, 49-62. [CrossRef]

157. Roldin, M.; Locatelli, L.; Mark, O.; Mikkelsen, P.S.; Binning, P.J. A simplified model of soakaway infiltration interaction with a shallow groundwater table. J. Hydrol. 2013, 497, 165-175. [CrossRef]

158. Roldin, M.; Mark, O.; Kuczera, G.; Mikkelsen, P.S.; Binning, P.J. Representing soakaways in a physically distributed urban drainage model-Upscaling individual allotments to an aggregated scale. J. Hydrol. 2012, 414-415, 530-538. [CrossRef]

159. Roldin, M.; Fryd, O.; Jeppesen, J.; Mark, O.; Binning, P.J.; Mikkelsen, P.S.; Jensen, M.B. Modelling the impact of soakaway retrofits on combined sewage overflows in a $3 \mathrm{~km}^{2}$ urban catchment in Copenhagen, Denmark. J. Hydrol. 2012, 452-453, 64-75. [CrossRef]

160. Locatelli, L.; Gabriel, S.; Mark, O.; Mikkelsen, P.S.; Arnbjerg-Nielsen, K.; Taylor, H.; Bockhorn, B.; Larsen, H.; Kjølby, M.J.; Blicher, A.S.; et al. Modelling the impact of retention-detention units on sewer surcharge and peak and annual runoff reduction. Water Sci. Technol. 2015, 71, 898-903. [CrossRef]

161. Petrucci, G.; Deroubaix, J.-F.; de Gouvello, B.; Deutsch, J.-C.; Bompard, P.; Tassin, B. Rainwater harvesting to control stormwater runoff in suburban areas. An experimental case-study. Urban Water J. 2012, 9, 45-55. [CrossRef]

162. Herrmann, T.; Schmida, U. Rainwater utilisation in Germany: Efficiency, dimensioning, hydraulic and environmental aspects. Urban Water 2000, 1, 307-316. [CrossRef]

163. Jones, M.P.; Hunt, W.F. Performance of rainwater harvesting systems in the southeastern United States. Resour. Conserv. Recycl. 2010, 54, 623-629. [CrossRef]

164. Guo, Y.; Baetz B., W. Sizing of Rainwater Storage Units for Green Building Applications. J. Hydrol. Eng. 2007, 12, 197-205. [CrossRef]

165. Vaes, G.; Berlamont, J. The effect of rainwater storage tanks on design storms. Urban Water 2001, 3, 303-307. [CrossRef]

166. Khastagir, A.; Jayasuriya, N.N. Impacts of using rainwater tanks on stormwater harvesting and runoff quality. Water Sci. Technol. 2010, 62, 324-329. [CrossRef] [PubMed]

167. Sterren, M.v.d.; Rahman, A.; Dennis, G.R. Implications to stormwater management as a result of lot scale rainwater tank systems: A case study in Western Sydney, Australia. Water Sci. Technol. 2012, 65, 1475-1482. [CrossRef] [PubMed]

168. Gowland, D.; Younos, T. Feasibility of Rainwater Harvesting BMP for Stormwater Management; Virginia Tech: Blacksburg, VA, USA, 2008; pp. 1-20.

169. Li, F.; Duan, H.-F.; Yan, H.; Tao, T. Multi-Objective Optimal Design of Detention Tanks in the Urban Stormwater Drainage System: Framework Development and Case Study. Water Resour. Manag. 2015, 29, 2125-2137. [CrossRef]

170. Palla, A.; Gnecco, I.; Lanza, L.G.; La Barbera, P. Performance analysis of domestic rainwater harvesting systems under various European climate zones. Resour. Conserv. Recycl. 2012, 62, 71-80. [CrossRef]

171. Sharma, A.K.; Gardner, T. Comprehensive Assessment Methodology for Urban Residential Rainwater Tank Implementation. Water 2020, 12, 315. [CrossRef]

172. Freni, G.; Liuzzo, L. Effectiveness of Rainwater Harvesting Systems for Flood Reduction in Residential Urban Areas. Water 2019, 11, 1389. [CrossRef]

173. Todeschini, S.; Papiri, S.; Ciaponi, C. Performance of stormwater detention tanks for urban drainage systems in northern Italy. J. Environ. Manag. 2012, 101, 33-45. [CrossRef] [PubMed]

174. Rahman, A.; Dbais, J.; Imteaz, M.A. Sustainability of rainwater harvesting systems in multistorey residential buildings. Am. J. Eng. Appl. Sci. 2010, 3, 73-82. [CrossRef] 
175. Imteaz, M.A.; Shanableh, A.; Rahman, A.; Ahsan, A. Optimisation of rainwater tank design from large roofs: A case study in Melbourne, Australia. Resour. Conserv. Recycl. 2011, 55, 1022-1029. [CrossRef]

176. Domènech, L.; Saurí, D. A comparative appraisal of the use of rainwater harvesting in single and multi-family buildings of the Metropolitan Area of Barcelona (Spain): Social experience, drinking water savings and economic costs. J. Clean. Prod. 2011, 19, 598-608. [CrossRef]

177. Morales-Pinzón, T.; Rieradevall, J.; Gasol, C.M.; Gabarrell, X. Modelling for economic cost and environmental analysis of rainwater harvesting systems. J. Clean. Prod. 2015, 87, 613-626. [CrossRef]

178. Zhang, Y.; Chen, D.; Chen, L.; Ashbolt, S. Potential for rainwater use in high-rise buildings in Australian cities. J. Environ. Manag. 2009, 91, 222-226. [CrossRef]

179. Roebuck, R.M.; Oltean-Dumbrava, C.; Tait, S. Whole life cost performance of domestic rainwater harvesting systems in the United Kingdom. Water Environ. J. 2011, 25, 355-365. [CrossRef]

180. Schubert, J.E.; Burns, M.J.; Fletcher, T.D.; Sanders, B.F. A framework for the case-specific assessment of Green Infrastructure in mitigating urban flood hazards. Adv. Water Resour. 2017, 108, 55-68. [CrossRef]

181. Huang, C.-L.; Hsu, N.-S.; Liu, H.-J.; Huang, Y.-H. Optimization of low impact development layout designs for megacity flood mitigation. J. Hydrol. 2018, 564, 542-558. [CrossRef]

182. Qin, Y.; Huang, Z.; Yu, Z.; Liu, Z.; Wang, L. A Novel Buffer Tank to Attenuate the Peak Flow of Runoff. Civ. Eng. J. 2019, 5, 2525-2534. [CrossRef]

183. Huang, H.; Chen, X.; Zhu, Z.; Xie, Y.; Liu, L.; Wang, X.; Wang, X.; Liu, K. The changing pattern of urban flooding in Guangzhou, China. Sci. Total Environ. 2018, 622-623, 394-401. [CrossRef] [PubMed]

Publisher's Note: MDPI stays neutral with regard to jurisdictional claims in published maps and institutional affiliations.

(C) 2020 by the author. Licensee MDPI, Basel, Switzerland. This article is an open access article distributed under the terms and conditions of the Creative Commons Attribution (CC BY) license (http://creativecommons.org/licenses/by/4.0/). 